\title{
Skin Infundibulocystic Basal Cell
}

\section{Carcinoma}

National Cancer Institute

\section{Source}

National Cancer Institute. Skin Infundibulocystic Basal Cell Carcinoma. NCI Thesaurus.

Code C27540.

A rare type of basal cell carcinoma. It is characterized by multiple tiny cysts lined by infundibular epithelium. 